\title{
Interferensi Leksikal Kosakata Ragam Bahasa Takresmi ke dalam Ragam Bahasa Resmi dalam Bahasa Indonesia
}

\author{
Mujid Farihul Amin \\ Prodi Sastra Indonesia, Fakultas Ilmu Budaya, Universitas Diponegoro \\ mujidfib@gmail.com
}

\begin{abstract}
Lexical interference is the entry of vocabulary from certain languages / languages into other languages / languages. In the use of official Indonesian languages, often people also use vocabulary commonly used in informal languages, such as kayak, bilang, bikin, cuman, cewek, nggak, dikasih, gitu, and gini. Good and right Indonesian should avoid things like that.
\end{abstract}

Keywords: lexical interference, informal language variety, official language variety

\section{Intisari}

Interferensi leksikal merupakan masuknya kosakata dari bahasa/ragam bahasa tertentu ke dalam bahasa/ragam bahasa yang lain. Dalam penggunaan bahasa Indonesia ragam resmi, sering juga orang menggunakan kosakata yang biasa digunakan dalam ragam bahasa tak resmi, seperti kayak, bilang, bikin, cuman, cewek, nggak, dikasih, gitu, dan gini. Berbahasa Indonesia yang baik dan benar harus menghindari hal-hal yang seperti itu.

Kata-kata Kunci: interferensi leksikal, ragam bahasa takresmi, ragam bahasa resmi

\section{Pendahuluan}

Bahasa adalah sistem lambang bunyi yang arbitrer yang digunakan untuk bekerja sama, berkomunikasi, dan mengidentifikasikan diri (Kentjono, 1988: 2). Sesuai dengan definisi tersebut, manusia sebagai mahluk sosial tentu membutuhkan interaksi dengan manusia lain. Untuk berinteraksi dengan manusia lain dalam kehidupan sehari-hari tentu akan menggunakan bahasa.

Dengan berbagai hal yang melatarbelakanginya, bahasa yang digunakan oleh manusia untuk berkomunikasi akan menghasilkan berbagai variasi bahasa. Variasi bahasa yang berbeda-beda menurut pemakaiannya inilah yang disebut dengan ragam bahasa. Misalnya saja bila dilihat berdasarkan sudut pandang penutur ada ragam bahasa daerah/logat/dialek, ragam bahasa terpelajar dan tidak; berdasarkan sudut paandang sifat penyampaian: ragam bahasa ilmiah, semi-ilmiah, dan non-ilmiah; berdasarkan sudut 
pandang jalur/sarana yang digunakan: ragam bahasa tulis dan ragam bahasa lisan; berdasarkan suasana: ragam bahasa resmi, takresmi, dan setengah resmi. Interferensi Leksikal adalah masuknya unsur bahasa yang berupa kosakata ke dalam bahasa lain yang dilakukan oleh seorang dwibahasawan atau orang yang menguasai lebih dari satu bahasa

Jadi, jika dipandang berdasarkan sudut suasananya dapat muncul ragam bahasa resmi, ragam bahasa tidak resmi, dan ragam bahasa setengah resmi. Permasalahan yang sering muncul adalah dalam suasana resmi sering orang menggunakan kosakata ragam bahasa takresmi. Ini yang disebut dengan interferenai leksikal. Interferensi Leksikal adalah masuknya unsur bahasa yang berupa kosakata ke dalam bahasa lain yang dilakukan oleh seorang dwibahasawan atau orang yang menguasai lebih dari satu Bahasa. Hal ini tentu saja tidak sesuai dengan maksud istilah "berbahasa Indonesia yang baik dan benar". Berbahasa Indonesia yang baik dan benar adalah berbahasa sesuai dengan suasana atau situasi dan sesuai dengan kaiadah-kaidah kebahasaan

\section{Rumusan Masalah}

Berdasarkan latar belakang di atas, rumusan masalah yang akan dikaji dalam penelitian ini adalah kosakata ragam bahasa tidak resmi apa saja yang sering digunakan dalam ragam Bahasa resmi dan bagaimana perilaku morfologi dan sintaksisnya.

\section{Tujuan}

Tujuan yang akan dicapai dalam penelitian ini adalah untuk mengetahui kata-kata apa saja dari ragam Bahasa tidak resmi yang sering digunakan dalam ragam Bahasa resmi dan bagaimana perilaku morfologis dan sintaksisnya.

\section{Manfaat}

Manfaat yang didapat dari hasil penelitian ini adalah dapat diperoleh gambaran yang jelas mengenai kosakata ragam Bahasa tidak resmi yang sering digunakan dalam ragam Bahasa resmi dan perlaku morfologis maupun sintaksisnya.

\section{Metode Penelitian}


Penelitian ini menggunakan tiga tahapan strategis seperti yang dikemukakan oleh Sudaryanto (1993: 5), yaitu: tahap pengumpulan data, tahap analisis data, dan tahap penyajian hasil analisis data.

Pada tahap pengumpulan data digunakan metode observasi.pengamatan dengan teknik dasar simak dan teknik lanjutan simak-libat-catat. Kemudian dalam tahap analisis data digunakan metode analisis dalam bidang morfologi dan sintaksis. Setelah selesai dianalisis, selanjutnya hasil analisis tersebut disajikan dengan menggunakan metode formal dan informal.

\section{Hasil dan Pembahasan}

Penutur bahasa yang positif adalah penutur Bahasa yang memperhatikan tepat tidaknya ragam Bahasa yang digunakan ketika berkomunikasi dengan penutur lain. Sebaliknya, penutur Bahasa yang ketika berkomunikasi tidak mempertimbangkan tepat tidaknya ragam Bahasa dapat dikatakan sebagai penutur yang bersikap negative terhadap penggunaan ragam Bahasa.

Untuk menjadi penutur yang bersikap positif terhadap penggunaan ragam Bahasa dan akhirnya bisa disebut berbahasa yang baik dan benar, tentu harus mampu memilahbedakan kosakata yang tepat digunakan dalam suasana resmi dan suasana tidak resmi. Untuk itu, penutur harus mampu mengidentifikasi kosakata ragam tidak resmi apa saja yang sering digunakan dalam suasana resmi.

Kosakata ragam bahasa tidak resmi yang sering muncul dalam suasana resmi ada beberapa, yaitu kayak, ngomong, bilang, bikin, cuman, cewek, cowok, nggak, dikasih, gitu, gini, kek, dan dong. Berikut akan dibahas satu per satu.

\section{Kata kayak}

Kata ini merupakan kata dalam ragam bahasa tak baku yang frekuensi kemunculannya sangat tinggi. Hal ini bisa dilihat pada data berikut.

(1) Kayak yang Bapak sampaikan tadi.

(2) Dia kayak kurang percaya diri ketika tampil di hadapan umum.

(3) Roy belum pernah merasakan kayak apa rasanya orang jatuh cinta. 
Dari data (1)-(3) bisa dilihat bahwa kata kayak bisa terletak pada berbagai posisi, bisa di depan maupun di tengah kalimat.

Kata kayak dalam ragam bahasa Indonesia resmi adalah kata seperti. Perhatikan (1a)-(3a) berikut.

(1a) Seperti yang Bapak sampaikan tadi.

(2a)Dia seperti kurang percaya diri ketika tampil di hadapan umum.

(3a) Roy belum pernah merasakan seperti apa rasanya orang jatuh cinta.

Selain itu, kata kayak juga bisa memperoleh afik (imbuhan) yang berupa sufik (akhiran) seperti terlihat pada data berikut.

(4) Kayaknya dia belum paham duduk persoalannya.

(5) Dia banyak melakukan kesalahan sendiri kayaknya kurang persiapan.

(6) Mereka belum memahami cara melakukan presentasi kayaknya.

Kata kayak akhir-akhir ini dalam pertuturan sering disederhanakan/ diringkas menjadi kek. Perhatikan data berikut.

(7) Kek mereka saja yang bisa mengerjakan soal itu.

(8) Saya kurang tahu kek apa makalah yang bagus ya.

(9) Masa kamu gak bisa kek gitu

\section{Kata bilang}

Kata bilang yang merupakan kosakata ragam Bahasa tidak resmi sering juga muncul dalam penggunaan ragam resmi. Kata bilang mempunyai kemungkinan letak di berbagai posisi, bisa di depan atau di tengah kalimat. Perhatikan contoh berikut.

(10) Mereka sudah bilang akan datang pagi ini.

(11) Saya sudah bilang kepada kalian semua materi pertemuan hari ini

(12) Bilang pada anggota lainnya untuk segera kumpul di sekretariat.

Kata bilang mempunyai padanan kata mengatakan/menyampaikan dalam ragam bahasa resmi. Hal ini bisa dilihat pada kalimat (10a)-(12a) berikut

(10a) Mereka sudah mengatakan akan datang pagi ini. 
(11a) Saya sudah mengatakan kepada kalian semua materi pertemuan hari ini

(12a) Katakan/sampaikan pada anggota lainnya untuk segera kumpul di sekretariat.

\section{Kata bikin}

Kata yang termasuk ragam Bahasa takresmi tetapi sering digunakan dalam ragam Bahasa resmi adalah kata bikin. Letak kata bikin dalam kalimat bisa di depan, tengah, atau belakang. Selain itu, kata bikin juga dapat menjadi kata turunan dengan penambahan afiks di-, -an, atau -in. perhatikan contoh kalimat berikut.

(13) Bikin aturan yang memuaskan semua pihak bukan perkara mudah.

(14) Baju itu bikinan mana?

(15) Masalah itu jangan dibikin manjadi lebih rumit.

(16) Seharusnya, kalian ikuti aturan dan tata tertib yang sudah dibikin.

\section{Kata cuman}

Kata cuman yang merupakan kosakata dalam ragam takresmi juga sering digunakan dalam ragam bahasa resmi. Kata tersebut juga mempunyai kemungkinan letak/posisi dalam kalimat yang relative bebas, bisa di depan atau di tengah. Perhatikan contoh berikut.

(17) Contoh kalimatnya cuman itu saja pak.

(18) Cuman dia yang bisa membuat pemuda itu bahagia.

(19) Kalau memang cuman dia yang bisa, bagaimana lagi.

\section{Kata cewek}

Kata lain dalam ragam bahasa takresmi tetapi sering digunakan dalam ragam resmi adalah cewek. Kata cewek mempunyai padanan dalam ragam resmi yaitu kata gadis. Letaknya dalam kalimat bebas, bisa di depan, di tengah, maupun di bagian belakang.

(20) Cewek itu bukan mahasiswa Undip.

(21) Kamu sudah punya cewek belum?

(22) Dia tidak menanggapi meskipun para cewek itu berusaha cari perhatian. 


\section{Kata nggak}

Kata dalam ragam takresmi yang sering juga masuk dalam tuturan resmi adalah nggak. Kata ini mempunyai padanan kata tidak dalam ragam bahasa resmi dan mempunyai kemungkinan posisi dalam kalimat yang bebas.

(23) Nggak masalah kalau kamu nggak bisa.

(24) Saya nggak bisa datang kalau acaranya nanti malam.

(25) Kamu mengerjakan tugas apa nggak?

\section{Kata dikasih}

Kata kasih dalam ragam bahasa takresmi yang sering masuk dalam tuturan resmi adalah yang berpadanan dengan kata beri dalam ragam bahasa resmi. Kata tersebut bisa mengalami afiksasi, baik berupa prefiks $d i$ - maupun dengan sufiks - $k a n$ dan -in. Lihat kalimat data dalam berikut.

(26) Dikasih uang berapa kamu sama dia?

(27) Saya belum dikasih tahu mengenai tugas itu.

(28) Barang itu sudah ditawar Rp50.000.00,00 tetapi nggak dikasih.

\section{Kata gitu}

Kata lain dlam ragam takresmi yang sering muncul dalam ragam resmi adalah gitu. Kata gitu merupakan bentuk lebih pendek dari kata begitu dalam ragam bahasa resmi.

(29) Menulis gitu saja kamu tidak bisa.

(30) Gitu saja dia sudah tersinggung.

(31) Dia sudah tidak mau menemuimu lagi gitu. 


\section{Kata gini}

Kata gini juga merupakan kata dalam ragam takresmi yang sering muncul ketika seseorang berbahasa dalam ragam resmi. Kata gini merupakan bentuk pendek dari kata begini dalam ragam resmi. Kata ini mempunyai kemungkinan letak dalam kalimat yang bebas, dapat di depan, di tengah, maupun di belakang.

(32) Gini saja kamu tidak mampu.

(33) Masalah gini sudah biasa bagik

(34) Masalahnya gini.

\section{Simpulan}

Kata-kata yang sering muncul dalam ragam formal seperti kayak, bilang, cewek, gini, gitu, kasih, ngomong hendaknya dihindari. Penutur harus bisa menenmpatkan diri dan mampu memilahbedakan penggunaan kata-kata sesuai dengan suasana atau situasinya.

\section{Daftar Pustaka}

Kentjono, Djoko. 1982. Dasar- dasar Linguistik Umum. Jakarta: Fakultas Sastra Universitas Indonesia.

Sudaryanto. 1993. Metode dan Aneka Teknik Analisis Bahasa: Pengantar Penelitian Wahana Kebudayaan secara Linguistis. Yogyakarta: Duta Wacana University Press

Chaer, Abdul dan Leonie Agustina. 2014. Sosiolinguistik: Perkenalan Awal. Jakarta: PT Rineka Cipta

Ramlan, M. 1997. Morfologi. Yogyakarta: CV Karyono.

Kridalaksana, Harimurti 1993. Kelas Kata dalam Bahasa Indonesia. Jakarta: PT Gramedia Pustaka Utama. 